\title{
O tribunal televisivo
}

Muniz Sodré e Raquel Paiva Universidade Federal do Rio de Janeiro/UFRJ 


\section{Resumo}

A apropriação caricatural e grotesca de aspectos da crise do sujeito de direitos por parte da programação de tevê. A transformação da atmosfera emocional da praça e das feiras para o espetáculo midiático. A semiose televisiva construída a partir das carências materiais e psíquicas das populações periféricas.

\section{Palavras-chave}

direitos, televisão, grotesco

\section{Abstract}

This text discusses some aspects of the contemporary crisis of the subject of rights and the way Brazilian television changes it into grotesque shows as well as the transformation of the emotional environment in squares and popular fairs into media shows. It also discusses how broadcast TV produces a particular semiosis out of material and psychological problems pertaining to urban lower classes.

\section{Key words}

rights, television, grotesque 


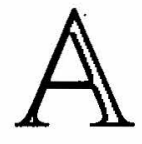

nedota contada num programa de variedades da televisão brasileira: muita gente acha que os laboratórios de pesquisa científica deveriam usar advogados em vez de ratos nas experiências. Por três razões: (1) Há mais advogados do que ratos; (2) com o passar do tempo, as pessoas acabam se afeiçoando aos ratos; (3) os ratos não são capazes de fazer qualquer coisa. A anedota - que deve ser ouvida como uma crítica à desmedida das ações judiciais e seus efeitos éticos colaterais - tinha como pano de fundo a notícia de que uma dona-de-casa norte-americana processou o marido por ter ele se esquecido de remover a neve do jardim.

$\mathrm{O}$ efeito de riso da história provém da crítica jocosa à desmedida das ações judiciais e seus efeitos éticos colaterais. Tudo isto é razoavelmente sabido, as anedotas poderiam multiplicar-se. A sociedade norte-americana tende a levar a seus limites e à exaustão o exercício do poder jurídico. Há muito tempo, processa-se por qualquer motivo, e qualquer gesto equívoco pode ser pretexto para uma ação judicial por assédio sexual.

Mas o que parecia traço exclusivo de uma sociedade que vive o seu sistema jurídico como uma quase-religião generaliza-se hoje, com algumas variações. Observa-se um desligamento progressivo da responsabilização atinente a campos específicos em favor do campo jurídico. Quando se processa penalmente um ministro de Estado em virtude, digamos, de um problema de contaminação da água potável (questão afeita a seu Ministério), está-se transferindo para a esfera jurídica um contencioso próprio da esfera administrativa ou da política de serviços públicos. Está-se alterando também a noção de crime como vontade deliberada de prática do mal. 
Por trás desse fenômeno desenha-se a crise contemporânea da política e das relações comunitárias, mas paradoxalmente do próprio Direito como instrumento teórico e prático para a resolução de conflitos intersubjetivos. Nas sociedades ditas pós-industriais e liberais de hoje, não apenas se altera a natureza dos conflitos sociais (defesa do ambiente, acesso à informação etc.) como também o tipo de espaço para a sua resolução. Em princípio, a questão se mostra no aparecimento de novos direitos e na jurisdicização de instâncias diversas da vida social.

No primeiro caso, trata-se da concretização social de direitos emergentes, sem que se cuide da adequação do aparelho judiciário, tanto em termos práticos como em sua legitimidade teórica, às novas demandas. Aparecem agora como titulares não apenas sujeitos coletivos de direitos - etnias, comunidades, gêneros etc. - em substituição ao homem individualizado e abstrato das clássicas declarações universais, mas verdadeiros sujeitos-objetos, a exemplo da Natureza, concebida no Direito Ambiental como titular de um direito à preservação.

No Brasil de hoje, ao lado de uma grande movimentação social em torno dos direitos da cidadania (onde o Ministério Público tem parte importante), a televisão popularesca costuma oferecer-se como um desses espaços de encenação e resolução de conflitos. A anedota dos advogados certamente terá um acréscimo de sentido se levarmos em consideração que foi contada durante um programa de televisão que se caracteriza pela encenação de conflitos.

Para melhor entender o fenômeno, é preciso inicialmente considerar alguns traços fundamentais da televisão brasileira. Como costuma acontecer nos países caracterizados pela via prussiana, isto é, pela modernização feita autoritariamente, de cima de baixo, a televisão chegou aqui de repente (desde 18 de setembro de 1950), por capricho de um empresário, sem estrutura industrial específica e, mesmo, sem número razoável de aparelhos receptores. Mas foi anunciada como um ícone do progresso nacional - O Brasil era o primeiro país na América Latina (o quinto no mundo) a dispor da novidade eletrônica. Nos quinze primeiros anos de funcionamento, havia menos de dois milhões de receptores em todo o país. 
O regime militar brasileiro foi a incubadora da expansão televisiva. Primeiro, estatais como a Eletrobrás e a Embratel, impulsionadas por motivos de ordem estratégica, eletrificaram e interligaram por sistemas de microondas o território nacional, criando as condições para a existência de uma rede nacional de televisão. Grupos empresariais brasileiros, associados a firmas eletroeletrônicas norte-americanas, encontraram no Estado militar o respaldo necessário para burlar a legislação vigente, introduzindo capitais, tecnologia e padrões de produção estrangeiros.

Finalmente, a repressão à liberdade de expressão, tanto nos espaços públicos e nas universidades como na imprensa, abriu espaço para o entretenimento vinculado ao mercado de consumo e à tevê. Dessa conjuntura - em que se davam as mãos militares, empresários e tecnoburocratas - surgiu a Rede Globo, o grupo economicamente mais poderoso e, em termos de programação, hegemônico na televisão brasileira.

O know-how do sucesso televisivo sempre foi claramente norte-americano: tratava-se de consolidar a audiência conquistada e de ampliá-la junto à periferia dos grandes centros urbanos (públicos definidos pela publicidade como $\mathrm{C}$ e $\mathrm{D}$ ), por meio das fórmulas melodramáticas já testadas e dos programas de auditório.

$\mathrm{O}$ auditório era um espaço de mediação (transicional, na terminologia do psicanalista Winnicott) entre a nova realidade daquilo que sociólogos chamaram de grandes bolsões urbano-industriais (São Paulo, Rio de Janeiro, Belo Horizonte, Porto Alegre) e a realidade tradicional, interiorana, das camadas populacionais que migram para os bolsões durante os anos 60. Na televisão, o auditório passou a exercer a mesma função que lhe garantira o grande sucesso na rádio: recriar a espontaneidade das festas e dos espetáculos públicos - portanto, assumir uma parte da tensão presente nas manifestações simbólicas das classes economicamente subalternas no espaço urbano - e ao mesmo tempo manipular os conteúdos popularescos, pondo-os a serviço da competição comercial/publicitária pelo mercado de audiência.

Nessa conjuntura televisiva, surgiram e impuseram-se programas no formato de feira livre, com grande sucesso de audiência, 
conduzidos por animadores como Chacrinha, Flávio Cavalcanti, Sílvio Santos, Hebe Camargo, Dercy Gonçalves, Jota Silvestre e outros. Como nas feiras de outrora, reprisavam-se aí as exibições do que Bakhtin chamou de curiosidades, ou seja, montava-se o espetáculo das anomalias humanas —aleijões, deformidades, aberrações da natureza, manifestações de idiotia etc.

Embora haja diferenças de organização dos textos e composição dos personagens, todos esses programas pautavam-se por recursos de rebaixamento de padrões, seja para reduzir a complexidade de mensagens e facilitar a sua assimilação por um público mais amplo, seja para estimular rebarbativamente o comportamento da platéia no auditório, levando os corpos a se movimentarem ao som da música ou as bocas a gritarem em uníssono com o animador. A fórmula - desfile de conflitos familiares, brigas de vizinhos, confissões de pequenos criminosos e viciados, geralmente alvos de duras diatribes morais do apresentador, aberrações diversas - seria retomada com sucesso na segunda metade dos anos 90 por programas como Ratinho e Leão.

Todo essa estética popular-televisiva desenvolve-se num quadro latino-americano e nacional, onde são cada vez mais exíguas manifestações culturais autônomas por parte das populações. A televisão impõe-se como o entretenimento hegemônico, com todos seus modos de ocultar e distorcer a realidade vivida. Um levantamento da CEPAL (Comissão de Planejamento Econômico da América Latina) revela que, entre os anos 80 e 90 , aumentou em 40 por cento o número de aparelhos receptores de tevê no continente, ao mesmo tempo em que, coincidentemente, diminuiu em 40 por cento a renda média dos assalariados.

No Brasil dos anos 90, especialmente após a elevação de consumo dos primeiros anos do Plano Real (1994), praticamente dobrou o número de aparelhos de tevê, uma vez que, naquele período, cerca de 6,3 milhões de domicílios receberam pela primeira vez o seu receptor. De modo parecido ao que havia ocorrido na segunda metade dos anos 60 depois do II Plano Nacional de Desenvolvimento (IIPND), constituiu-se perto da virada do milênio uma camada nova de telespectadores, muito pouco alfabetizada e ávida de diversão barata. 
Há quem se refira à televisão como janela para o inferno e há também quem credite esse aumento no tempo de exposição ao ingresso massivo dos programas do tipo reality show, que na verdade nada mais são do que uma sensível redução (frequentemente grotesca) da fronteira entre o telejornalismo e o entretenimento. Com efeito, na televisão aberta do Brasil, apesar da consolidação da audiência pelas redes (resguardada sempre a hegemonia da Globo), mantém-se como recurso de apelo crescente uma estética do grotesco, responsável pelo formato popularesco hegemônico.

Predominam hoje dois padrões de programação: o de qualidade, ou seja, esteticamente clean, bem comportado em termos morais e visuais e sempre fingindo jogar do lado da cultura, e o do grotesco, onde se desenvolvem as estratégias mais agressivas pela hegemonia de audiência.

A televisão, como um sistema, é uma ambiência abrangente, que implica todo um estilo de vida, a reboque do mercado e da estetização orquestrada pela tecnologia comunicacional. A política partidária e regional tem uma parte importante nesse jogo. Uma rede como a Globo ramifica o seu poder junto a elites políticas (e geralmente familiares) regionais, por meio de emissoras afiliadas, hibridizando a modernidade transnacional do Centro-Sul com o arcaísmo coronelista do Norte e Nordeste.

Semioticamente, a televisão e seu público terminam confundindo-se. Como sugeriu Lacan, não existe mais diferença entre a televisão e o público depois de algum tempo. De fato, a principal matéria-prima para os conteúdos discursivos da tevê são as representações sociais, no sentido de forma de conhecimento a partir do senso comum e orientada para a figuração de uma realidade qualquer. $\mathrm{Na}$ fronteira do individual com o social, essas representações incorporam conteúdos (opiniões, atitudes, informações) realistas e imaginários, relativos à vida cotidiana, reorganizando-os numa modalidade de saber adaptada à fácil comunicação.

As representações resultam da ação comunicativa entre indivíduos e grupos: a força de seu trânsito social relativiza a dicotomia indivíduo/grupo. Ou seja, a representação social em vigor contém potencialmente a metáfora de um corpo grupal, apoiada em imagens 
e fantasias comuns a todos os membros da coletividade. Na sociedade midiatizada de hoje, a televisão, enquanto mídia hegemônica, tende a instituir-se como esse corpo grupal, reinterpretando semioticamente determinados discursos do senso comum.

Daí, a afirmação de uma identidade entre a televisão e seu público. Atuando sobre a imediatez da vida cotidiana - um mundo comum a todos e com pontos de semelhança, aos quais cada indivíduo se vincula por numerosas conexões sociais - , regulando ou interagindo com seu fluxo, a televisão literalmente incorpora-se à idéia que o indivíduo tende a fazer de si mesmo e de seus pares.

E essa idéia, na tevê aberta, privilegia fortemente a ótica do grotesco. Primeiro, porque suscita o riso cruel, que parece assumir contemporaneamente foros de liberdade de pensamento. A hilaridade sempre foi um vitorioso recurso universal na mídia, mas agora se impõe com um novo estilo, em que a crueldade - entendida ora como gozo com o sofrimento do outro, ora como nenhuma contemplação ética para com o tema em pauta - é o traço principal.

É um tipo de riso massivo, pretensamente democrático, em que antigos objetos de indignação (miséria, opressão, falta de solidariedade, descaso dos poderes públicos, etc.) recaem na indiferença generalizada. Quando Bakhtin disserta em sua obra sobre as formas de cultura folclórica carnavalesca, inclui, ao lado dos espetáculos rituais e composições cômicas, os vários estilos de linguagem chula, onde pontificam blasfêmias e profanações. Este último contexto é fortemente reaproveitado pela tevê aberta. Nele, não se medem palavras e pode-se rir de tudo - do sofrimento, da dominação, da brutalidade, do ridículo alheio.

Segundo, porque a impotência humana, política ou social de que tanto se ri é imaginariamente compensada por sorteios e prêmios (financiados pelos patrocinadores comerciais dos programas), assim como pela possibilidade de que conflitos pessoais venham a ser resolvidos pelos produtores do programa.

Um exemplo disso é o caso de uma mulher que teve os olhos furados e os órgãos genitais dilacerados pelo marido embriagado, que fugiu em seguida. Durante dois anos, ela buscou inutilmente a ajuda do Estado para realizar as cirurgias que lhe aliviassem as dores. 
Comparecendo finalmente ao "Programa do Ratinho", encontrou a solução para seus males: foi encaminhada a um hospital, onde pôde ser operada gratuitamente; seu agressor foi localizado e preso em outro estado da Federação brasileira.

Em resumo, em face do sentimento crescente de que nenhuma política de Estado promete ou garante mais o bem-estar coletivo, a desesperança das camadas mais baixas das classes periféricas é amenizada por jogos que envolvem a Providência e o Destino.

Terceiro, porque o grotesco chocante - esta é a modalidade dominante nas programações televisivas para a grande massa permite encenar o povo e, ao mesmo tempo, mantê-lo à distância. Dão-se voz e imagem a energúmenos, ignorantes, ridículos, patéticos, violentados, disformes, aberrantes, para mostrar a crua realidade popular, sem que o choque daí advindo chegue às causas sociais, mas permaneça na superfície irrisória dos efeitos.

Esses elementos fazem-se presentes, como se fossem cláusulas contratuais, no contrato de leitura que a televisão estabelece com seu público. A idéia desse contrato, popularizada pelos estudos (acadêmicos) de recepção dos produtos comunicacionais, é a mesma de um pacto simbólico implícito na relação entre o sistema tecnomercadológico da tevê aberta e a sua audiência. Por isso, as emissoras de televisão podem afirmar, após a sua regular aferição por institutos de pesquisa, que oferecem em sua programação aquilo que o público deseja ver.

$\mathrm{Na}$ realidade, as emissoras oferecem aquilo que elas e seu público desejam ver. De fato, o sistema televisivo-mercadológico constituiu esse público que, ao longo dos anos, tornou-se ele próprio audiência de tevê. Os arautos do moralismo culturalista tendem a explicar o fenômeno pela vitimização do público: a massa analfabeta e socialmente desarraigada seria vítima de um sistema absolutamente perverso, que poderia, mas não quer, oferecer uma programação formativa, de nível cultural mais elevado.

A audiência, entretanto, não é vítima, e sim cúmplice passivo de um ethos a que se habituou. Na sub-urbs miserável e desesperançada abandonada pelos serviços públicos do regime neoliberal, costuma-se sonhar com o Acaso que levará o aquinhoado 
pela Sorte a ser chamado pela produção de um reality-show para transformar em espetáculo o seu sofrimento pessoal, a sua aberração existencial e sair com um eletrodoméstico qualquer como prêmio, senão com a promessa de um emprego.

Seria, entretanto, uma simplificação fazer dessa cumplicidade entre sistema televisivo e audiência um atributo exclusivo das camadas muito pobres da população, na suposição de que os mais abastados migraram para a tevê por assinatura. A verdadeira migração é do grotesco para praticamente todos os tipos de programação da tevê aberta - uma espécie de tropismo ou direcionamento fatal para o grotesco - inclusive aqueles antes reputados como de qualidade.

De fato, após décadas de rebaixamento de padrões, o público em geral tornou-se esteticamente parte disso que os especialistas chamam de trash, tentando com a designação em inglês hierarquizar culturalmente a realidade do lixo semiótico reciclado e transmitido. Tudo isso forma hábito e atmosfera emocional. Mas tem principalmente um efeito de contaminação semiótica (uma espécie de reprodução viral dos simulacros à maneira da lei de Gresham, segundo a qual a moeda má expulsa a boa), não por uma lógica intrínseca das imagens, mas pela força catalisadora do marketing num contexto de livre concorrência ou livre circulação da moeda televisiva, em que a facilitação e a banalidade convertem-se em recursos de fácil captação de audiência.

O fenômeno não se limita ao vídeo. Por exemplo, todo o episódio da eleição e curta permanência no poder do presidente Fernando Collor é permeado por claro rebaixamento de padrões de estética pública e de comportamento pessoal. $\mathrm{O}$ apelo latente à animalidade presente na constante invocação da força corporal — para resolver problemas nacionais, como inflação, corrupção etc., e a exibição brega de façanhas esportivas, querelas familiares e anacrônicas atitudes de corte imperial concorriam para a tipificação de um grotesco atuado. Guardadas as proporções, é a mesma linha de personalidades como Idi Amin Dada, Bokassa, George Bush e outros.

$\mathrm{Na}$ tevê, o olhar é economicamente captado com vistas a uma rentabilidade de mercado, de natureza publicitária. Até mesmo uma emissora sem finalidades comerciais (estatal, pública, educativa) 
termina competindo no mercado por audiência. Aos poucos, todas as imagens programadas dentro desse sistema mercadológico tendem a seguir apenas a lógica da captação do olhar, por mais grosseira ou rebarbativa que seja.

As pessoas olham (assim como se mira o ambiente ao redor) mais do que vêem alguma coisa na televisão - o receptor ligado, mas silencioso, em bares e restaurantes, é sintomático. E como a realidade das imagens é descorporificada, sem profundidade simbólica, o choque do grotesco, pregnante em sua evocação vitalista da corporalidade, excita o olhar do espectador. É a estética que termina impondo-se como horizonte signico da tevê aberta, simulacro de espaço público num tipo de sociedade em que público equivale cada vez mais a feira de variedades.

Mas é um público que penetra no espaço íntimo ou familiar do espectador, razão pela qual as imagens têm de simular uma familiaridade, interpelar o telespectador como se fosse um próximo, donde o acúmulo de índices de proximidade, de hipersignificação das situações e dos objetos, mas também de simulação de instituições destinadas a resolver conflitos pessoais ou sociais na realidade histórica.

Seria enganoso supor que tudo isso seja exclusivo da televisão terceiro-mundista, em especial a brasileira. Na modernidade tardia que experimentamos, expande-se um imaginário teratológico e escatológico, como consequiência das mutações identitárias e da instabilidade das representações, constantes fontes de ameaças para o humanismo tradicional.

As sombras da banalidade e da bestialização acompanham igualmente esse imaginário, que o crítico italiano Omar Calabrese chama de neobarroco, mas que se encaminha em seus formatos de entretenimento público para a estética do grotesco chocante. No caso específico da tevê aberta, monstruosa é quase sempre a representação do povo, contrastado com a elite consumidora. Os feios, os disformes, os miseráveis, os discriminados - seres tendencialmente colocados na lata de lixo do esteticamente correto - são exibidos como conformações dissipativas da imagem humana. Neles, a periferia pode reconhecer-se; deles a elite pode distinguir-se: a televisão é o lugar da síntese. 


\section{Ratinho e seu auditório}

Toda a síntese televisiva é regida pela estética do grotesco, mas geralmente presta-se mais atenção e se dirigem mais críticas aos formatos de auditório mais óbvios ou mais rebarbativos, como o programa do Ratinho, que é modelar. Ratinho é o apresentador Carlos Massa, homem de raciocínio rápido, um tanto truculento. Os quadros apresentam geralmente dramas familiares, que são resolvidos pela mediação do apresentador e de seus personagens/animadores, escolhidos, ao que tudo indica, por suas peculiares características físicas: uma anã, um obeso negro, um rapaz de cabelos longos e trejeitos efeminado, um negro muito alto e forte e outros.

Conflito é o nome do primeiro quadro do programa, com exibição garantida todos os dias. As duas partes de uma briga são chamadas e postas à frente, para explicar o caso e tentar uma solução. Os casos mais comuns são litígios por terrenos e casas, dívidas não saldadas, traições conjugais, problemas de família. A produção do programa oferece advogados para tentar obter um acordo ou encaminhar a questão à Justiça. Outras vezes, quando o problema gira em torno de quantias inferiores a três mil reais, o programa se dispõe a pagar, para acabar com a discórdia.

Não raro, porém, um dos litigantes avança para o outro, insultando e tentando agredi-lo. Aí então, o apresentador não tenta estancar o conflito: devidamente protegido, a uma boa distância guardada, limita-se a comentários. Os personagens/animadores colocam-se na postura ambígua de, simultaneamente, tentar separar e insuflar ainda mais os ânimos, por meio de urros, gargalhadas, gestos estimuladores. A platéia adquire grande importância no clima de bagunça, à moda das feiras, que a produção e os animadores estimulam.

Algumas vezes, os próprios envolvidos concordam em resolver seus problemas amistosamente: fazer testes de DNA para comprovação de paternidade, pagar pensões ou simplesmente aparecer no programa para discutir o assunto, já que em boa parte dos casos o conflito consiste exatamente na procura de um pelo outro, na tentativa de reaproximação ou similar. Nos casos de impasse, o Ratinho 
intervém, tentando negociar ou convocando a produção do programa para assumir o fechamento do caso.

Noutro quadro, tribuna de pedidos, instalam-se numa espécie de tribuna pessoas que, angustiadas, pedem a Ratinho solução para seus problemas. De todo tipo: uma mulher procura a mãe, que a abandonou há 30 anos; uma senhora não consegue dormir; outra pessoa quer uma cadeira de rodas etc. Aqui, exibe-se um vídeo dramático sobre a situação e, ao final, gira-se uma porta, para se saber se o pedido foi atendido ou não. Geralmente, a resposta é positiva, seja na forma do objeto solicitado ou na de uma pessoa que explicará os procedimentos para obter-se o desejado. Às vezes, o pedinte recebe muito mais do que pediu, a depender do nível de dramaticidade e de empatia por sua situação.

Alheias ou indiferentes às críticas intelectuais, parcelas significativas do povo da periferia urbana de São Paulo comparecem a esse tipo de programa, parecendo aprofundar um pacto simbólico com a televisão. É um pacto perverso, porque vem em nome de uma das bandeiras da modernização republicana, que é o universalismo democrático dos direitos. A mídia, especialmente eletrônica, atenderia a um desejo e a um direito de comunicação instantânea, possibilitada pelas tecnologias da informação, com o acréscimo de circo contínuo para as massas.

$\mathrm{Na}$ realidade, porém, a atitude republicana tem pouco de universal e muito do que caracterizou a república brasileira: uma elite mascarada de europeu, desfilando sua pretensa modernidade para um povo bestializado. Ou melhor, para um público bestializado, pois, como já sustentava Lima Barreto, O Brasil não tem povo, tem público. 